\title{
Cluster-complex mediated electron-transfer and ATP hydrolysis
}

\author{
Yehuan Wu, Hongbo Chen, Guodong Lin, Xinsheng Yu, Hongtu Zhang, \\ Huilin Wan, and Khirui Tsai \\ Department of Chemistry and Institute of Physical Chemistry, \\ Xiamen University, Xtamen, Fujian, China
}

\begin{abstract}
Chemical-modeling studies of ATP-driven electron-transfer in nitrogenase reactions show that ATP can complex with $\left(\mathrm{Fe}_{4} \mathrm{~S}_{4}(\mathrm{SPh})_{4}\right)^{2-}$ cluster (without displacing any of the thiolate liqands and without shielding the cubane-like cluster from disruption by iron chelaters), resulting in suppression of electronic absorption peak at $458 \mathrm{~nm}$, in down-field shifting of the $31 \mathrm{P}$ n.m.r. peaks of $\alpha-, \beta-$, and $\gamma-\mathrm{PO}_{4}$ of ATP by about $8.2 \mathrm{ppm}$, $7.9 \mathrm{ppm}$, and $10 \mathrm{ppm}$, respectively, and in shifting the polarographic halfwave potential from $-1.00 \mathrm{~V}$ to $-1.49 \mathrm{~V}$, as well as in significant enhancement of the rate of redox reaction between the cubane-like cluster and indigo carmine, or methylene blue, with no detectable ATP hydrolysis. A small extent of ATP hydrolysis (ca. 14\%; in DMF-water, $3: 2 \mathrm{v} / \mathrm{v}$, and pH 7.0) was observed, however, when the cubane-ATP complex was oxidized with hydrogen peroxide at room temperature. These results are in line with the mechanism of ATP-driven electron-transfer previously proposed by us.
\end{abstract}

\section{INTRODUCTION}

Nitrogenase is a complex metallo-enzyme consisting of two metallo-protein components: component 1 , the MoFe-protein, consists of 4 subunits $\left(\omega_{2} \beta_{2}\right)$ and carries the substrate-binding site; and component 2 , the Fe-protein, consists of two identical subunits $\left(\gamma_{2}\right)$ with a cubanelike $4 \mathrm{Fe}-4 \mathrm{~S}$ cluster anchored between them probably through 4 cysteinyl-thiolate ligands, and serves as a specific one-electron carrier to transport electrons to the MoFe-protein with the aid of MgATP as "electron activator, each molecule of the Fe-protein being able to complex with 2 molecules of MgATP, which are hydrolyzed into 2 MgADP and 2 Pi (inorganic phosphate), practically coneurrently with the electron-transfer from the reduced Fe-protein to the semireduced MoFe-protein (ref. 1, 2). This ATP-driven electron transfer in nitrogenase catalysis is an important example of coupled electron and energy transports in biochemical processes, and has been the subject of extensive investigations since the late 1960s; but just how this "electron activation" works is still an unresolved problem. For example, the site of MgATP binding is still more or less a matter of speculation. In view of the fact that complexation of MgATP with the reduced Fe-protein renders the $4 \mathrm{Fe}-4 \mathrm{~S}$ center readily susceptible to disruption by batho-phenanthroline iron-chelater, most investigaters hold the views that the two molecules of MgATP are not bound to the cubane-like center, but to some other parts of the Fe-protein, causing a conformational change to take place with greater exposure of the 4Fe-4S center, and that hydrolysis of the bound MgATP brings about further conformational change to drive the electron-transfer to the MoFe-protein. However, there are some weaknesses in this view: the nature of the bonding of MgATP with the Fe-protein is left unspecified; moreover, it is a known experimental fact that complexation of MgATP with the reduced or oxidized Feprotein alone without the protein-protein electron-transfer does not lead to appreciable promotion of ATP hydrolysis; so the mechanism of ATP hydrolysis, which has been shown to take place at practically the same rate as the protein-protein electron-transfer (ref.3), is also left unexplained. Since the Fe-protein is known to be sensitized by ATP, GTP, or pyrophosphates to inactivation and oxidation by air (ref. 1), and since these reagents are known to be efficient iron chelaters, it seems to us that the $4 \mathrm{Fe}-4 \mathrm{~S}$ center of the Fe-protein may be accessible to these iron chelators.

Based upon the principles of coordination catalysis (ref. 4), a mechanism of 2-step ATPdriven electron-transport in nitrogenase catalysis has been proposed and developed by us (ref. 5) consisting of the following essential points: (1) coordination of MgATP (to be denoted by $\mathrm{t}$ ) to the $4 \mathrm{Fe}-4 \mathrm{~S}$ center of the reduced Fe-protein (to be denoted by [2s], where the subscript's signifies that this species is e.p.r. active, having characteristic e.p.r. sig$\mathrm{nal}$ ), to form [ $2 \mathrm{st}$ ] produces a conformational change and raises the ligand field acting on the $4 \mathrm{Fe}-4 \mathrm{~S}$ center todrive the electron-transfer to the e.p.r. active, semi-reduced MoFe-protein,

This work is supported by the Chinese National Science Foundation. 
$\left[l_{s}\right]$, resulting in the formation of the e.p.r. silent, oxidized Fe-protein and the e.p.r. silent, reduced MoFe-protein, [10]; (2) this electron outflow from the Fe-protein greatly promotes the hydrolysis of each of the two coordinated $t$ into MgADP (d) and inorganic phosphate ( $\mathrm{Pi}$ ), thus the enzyme complex is now in the state [10][2gd, 2Pi]; (3) this enzyme complex dissociates into its two protein components for the release of the entrapped 2Pi and for successive displacement of the two coordinated $\underline{d}$ by $t$, as well as for replenishment of an electron from the reductant; (4) a second step of ATP-driven electron-transfer, this time from [ $\left.\mathrm{I}_{0}\right]$ to the coordinated substrate without ATP hydrolysis, appears to be necessary since [10] alone without the Fe-protein and $t$ is known to be unable to reduce substrates; this may be accomplished by complexation of $\left[\mathrm{l}_{0}\right]$ with $[2 \mathrm{st}]$, or even with [2tt], which may also have sufficiently negative redox potential to prevent the MoFe-protein-to-Fe-protein electronbackflow; and (5) electron backflow may take place, however, whenever ]2o] or [20], before coordinating $t$, has a chance to complex with [10].: This proposed mechanism of 2-step ATPdriven electron-transfer can explain (ref. 5-6) the redox states of the enzyme components, as revealed by the presence or absence of e.p.r. signals, at the steady state of the enzyme turnover, or at insufficient supply of reductant or ATP, as observed by Walker and Mortenson (ref. 7) with dilute solution of nitrogenase from C. pasteurianum (Cp) where the complexation of [10] with [2tt] or [ $\left.2_{0}^{t t}\right]$ may be slow enough to be rate controlling.

Some support of this proposed mechanism has been obtained by Chen et al. (ref. 8) from the observed effects of ATP on electronic absorption spectra and polarographic half-wave potential of synthetic $4 \mathrm{Fe}-4 \mathrm{~S}$ cubane-like clusters, and on the rate of redox reaction of one of these clusters with methylene blue (M.B.).

This paper reports further support from similar chemical-modeling experiments with $\left(\mathrm{Fe}_{4} \mathrm{~S}_{4}(\mathrm{SPh})_{4}\right)^{2-}$ as a model compound of the $4 \mathrm{Fe}-4 \mathrm{~S}$ center of the oxidized Fe-protein, showing the effect of the cluster on the chemical shifts of the 31P n.m.I. peaks of MgATP, or ATP in DMF-D O solution, and the effects of ATP on the thiolate ligands, on the rates of disruption of the cluster by phenanthroline, and of: oxidation by indigo carmine (In), as well as on the extent of ATP hydrolysis promoted by the oxidation of the cluster with hydrogen peroxide in DMF-water.

\section{EXPERIMENTAL}

\section{Materials}

All the chemicals used were of A.R. or C.P. grades. Purification of ATP (biochemical reagent from Shanghai Biochemical Research Institute of the Chinese Academy of Sciences) to an ATP content of greater than $98 \%$ was done according to known method of ion-exchange. Dimethyl formamide (DMF' of A.R. grade was freshly distilled before use. Stock solution of the redox dye indigo carmine ( In) in DMF was prepared in $5.0 \mathrm{mM}$, and that of phenanthroline (phen) in DMF, $10 \mathrm{nM}$. Quarternary ammonium salts of the cubane-like cluster (e.g., the tetra-ethyl ammonium salt ( $\left.\mathrm{Et}_{4} \mathrm{~N}\right)_{2} \mathrm{Fe}_{4} \mathrm{~S}_{4}(\mathrm{SPh})_{4}$ ) were prepared according to known methods (ref. 9-10) and identified by their electronic absorption spectra. Non-aerobic experiments were all conducted in thoroughly deoxygenated argon atmosphere.

\section{Effect of $\left(\mathrm{Fe}_{4} \mathrm{~S}_{4}(\mathrm{SPh})_{4}\right)^{2-}$ on ${ }^{31} \mathrm{P}$ n.m.r. spectrum of ATP in DMF-D $\mathrm{D}_{2} \mathrm{O}$}

To $4.0 \mathrm{ml}$ of $\ddot{1} 15 \mathrm{mM}$ solution of $\left(\mathrm{Et}_{4} \mathrm{~N}\right)_{2} \mathrm{Fe}_{4} \mathrm{~S}_{4}(\mathrm{SPh})_{4}$ in DMF was added $1.0 \mathrm{ml}$ of $150-\mathrm{mM} \mathrm{ATP}$ in $\mathrm{D}_{2} \mathrm{O}$ (the $\mathrm{pH}$ being adjusted to 7.0 with dilute $\mathrm{NaOH}$ in $\mathrm{D}_{2} \mathrm{O}$ ). The DMF: $\mathrm{D}_{2} \mathrm{O}$ ratio $(4: 1 \mathrm{v} / \mathrm{v})$ was found to be sufficient to keep the cluster complex in solution while the excess ATP largely undissolved. The mixture was shaken and allowed to stand in thoroughly deoxygenated argon atmosphere for 20 minutes, then centrifuged to remove the excess ATP; $2.5 \mathrm{ml}$ of the supernatant liquid were transferred to n.m.r. cell, and the $3 l_{P}$ n.m.r. spectrum of the sample taken with a Varian FT-80A n.m.r. spectrometer, with $\mathrm{Na}_{2} \mathrm{HPO}_{4}$ in $\mathrm{D}_{2} \mathrm{O}$ as external strandard. Likewise, the $3 l_{\mathrm{P}}$ n.m.r. spectra of samples prepared by treating $4.0 \mathrm{ml}$ of $15-\mathrm{m}$ solution of $\left(\mathrm{Et}_{4} \mathrm{~N}\right)_{2} \mathrm{Fe}_{4} \mathrm{~S}_{4}(\mathrm{SPh})_{4}$ in DMF with $1.0 \mathrm{ml}$ of $150-\mathrm{mM}$ solution of ADP (or AMP, or Pi) in $\mathrm{D}_{2} \mathrm{O}$ were taken, as well as the 31 n.m.r. spectra of samples of ATP, ADP, and AMP, each in about 20$\mathrm{mM}$ solution in $\mathrm{D}_{2} \mathrm{O}$, and of an $\mathrm{ATP}$ solultion in $\mathrm{D}_{2} \mathrm{O}$ containing an equivalent amount of $\mathrm{HSC}_{2} \mathrm{H}_{4} \mathrm{OH}$. The $3 \mathrm{i}_{\mathrm{P}}$ n.m.r. peaks of the $\alpha-\beta^{-}$, and $\gamma-\mathrm{PO}_{4}$ of ATP were labelled according to the literature (ref. 11).

\section{Detection of any free thiophenol in $\left(\mathrm{Fe}_{4} \mathrm{~S}_{4}(\mathrm{SPh})_{4}\right)^{2-}-\mathrm{ATP}$ mixture in DMF- $\mathrm{H}_{2} \mathrm{O}$}

The mixture of the cluster compound (1.0 mM) and ATP in DMF- $\mathrm{H}_{2} \mathrm{O}(4: 1 \mathrm{v} / \mathrm{v}$, Tris $\mathrm{HCl} 25 \mathrm{mM}$, pH 7.6) was extracted with n-heptane for any free thiophenol, and the extract treated with silver dithiazon (AgDz) in carbon tetrachloride solution prepared according to standard method of silver dithiazon test (ref. 12) for the detection of trace thiophenol;

$\left(\mathrm{Fe}_{4} \mathrm{~S}_{4}(\mathrm{SPh})_{4}\right)^{2-}$ in $\mathrm{DMF}-\mathrm{H}_{2} \mathrm{O}(4: 1 \mathrm{v} / \mathrm{v}$, Tris $\mathrm{HCl} 25 \mathrm{mM}, \mathrm{pH} 7.6)$ being used as reference for the colorimetry of the thiophenol - AgDz color test at $615 \mathrm{mpl}$.

\section{Effect of ATP (ADP, AMP, or Pi) on rate of disruption of $\left(\mathrm{Fe}_{4} \mathrm{~S}_{4}(\mathrm{SPh})_{4}\right)^{2-}$ by phenanthroline in DMF- $\mathrm{H}_{2} \mathrm{O}(3: 2 \mathrm{v} / \mathrm{v})$}

In a $0.5-\mathrm{cm}$ spectrophotometric cell closely fitted with stopper were placed $1.5 \mathrm{ml}$ of $\mathrm{DMF}-$ $\mathrm{H}_{2} \mathrm{O}(3: 2 \mathrm{v} / \mathrm{v}$, Tris $\mathrm{HCl} 25 \mathrm{mM}$, $\mathrm{pH} 7.5)$ containing 0.15 mol $\left(\mathrm{Fe}_{4} \mathrm{~S}_{4}(\mathrm{SPh})_{4}\right)^{2-}$ and 1.5 umol ATP; 
then $0.3 \mathrm{ml}$ of $10-\mathrm{mM}$ phen in DMF was quickly added and the electronic absorption at $510 \mathrm{mu}$ recorded with time. Similar spectrophotometric experiments were performed with samples containing, separately, 1.5 umol ADP, $1.5 \mu \mathrm{mol}$ AMP, and $1.5 \mu \mathrm{mol} \mathrm{Pi}$, instead of the $1.5 \mu \mathrm{mol}$ ATP; and with a reference containing only the cluster and phen in the same medium.

\section{Effect of ATP (ADP, AMP, or Pi) on rate of redox reaction between the cluster and}

\section{indigo carmine in DMF- $\mathrm{H}_{2} \mathrm{O}$}

Into 1-cm spectrophotometric cells with closely fitted stoppers were introduced $2.0 \mathrm{ml}$ of $0.05-\mathrm{mM}\left(\mathrm{Fe}_{4} \mathrm{~S}_{4}(\mathrm{SPh})_{4}\right)^{2-}$ in $\mathrm{DMF}$ and $0.50 \mathrm{ml} \mathrm{H} \mathrm{H} \mathrm{O}$ containing 1.0 umol of ATP, or ADP, or Pi (each adjusted to $\mathrm{pH} 7.0$ with $50-\mathrm{mM}$ Tris $\mathrm{HCl}$ buffer). After standing for 20 minutes, $0.15 \mathrm{ml}$ of 0.50-mM indigo carmine in DMF was quickly added, and the rate change in optical density at $610 \mathrm{mu}$ was recorded spectrophotametrically.

\section{Determination of extent of ATP hydrolysis promoted by reactions between the cluster and redox dye or hydrogen peroxide}

Phosphate ions ( $\mathrm{Pi}$ ) liberated from ATP hydrolysis may be determined by a modification of Baginski's molybdenum blue method (ref. 13). With MgATP, or ATP-oxidant (M.B.) as reference, the amount of $\mathrm{Pi}$ liberated from $\left(\mathrm{Fe}_{4} \mathrm{~S}_{4}(\mathrm{SPh})_{4}\right)^{2--}-\mathrm{MgATP}$, and from $\left(\mathrm{Fe}_{4} \mathrm{~S}_{4}(\mathrm{SPh})_{4}\right)^{2-}-\mathrm{MgATP}-\mathrm{M} . \mathrm{B}$. may be determined sparately by the modified molybdenum blue method by subtracting the amount of $\mathrm{Pi}$ determined in the reference from the total amount of $\mathrm{Pi}$ determined in each of the test systems.

Since both methylene blue and the cluster interfere seriously with the molybdenum blue colorimetry, these must be removed by extraction before the additon of the molybdenum blue color developing reagents. Methylene blue cation and perclorate anion can from chloroform: soluble ion-pair; so, in the presence of $\mathrm{ClO}_{4}^{-} \mathrm{M} . \mathrm{B}$. can be extracted with chloroform. The actual procedure adopted was, after the addition of $5.0 \mathrm{ml}$ of $10-\mathrm{mM} \mathrm{NaClO} 4$ and $3-\mathrm{M} \mathrm{NaCl}$ to $3.0 \mathrm{ml}$ of each of the samples, the mixture was extracted with $2.0 \mathrm{ml}$ cloroform with vigorous shaking for 4 minutes, and then centrifuged; $5.0 \mathrm{mI}$ of the clear upper layer (aqueous) were extracted twice with $2 \mathrm{ml}$ chloroform. Finally, the clear aqueous layer was used for the determination of $\mathrm{Pi}$ by the modified molybdenum blue method (ref. 13).

For the determination of $\mathrm{Pi}$ liberated from ATP in the redox reaction between the cluster and. hydrogen peroxide in the presence of ATP, in DMF- $\mathrm{H}_{2} \mathrm{O}(3: 2 \mathrm{v} / \mathrm{v})$, the following procedure was used. To $3.0 \mathrm{ml}$ of the sample containing 30 jmol ATP and 30 umol ( $\mathrm{Fe}_{4} \mathrm{~S}_{4}(\mathrm{SPh})_{4}$ )2- reacted with $60 \mathrm{umol} \mathrm{H}_{2} \mathrm{O}_{2}$ in $\mathrm{DMF}-\mathrm{H}_{2} \mathrm{O}(60: 40 \mathrm{v} / \mathrm{v})$ were added $0.30 \mathrm{ml}$ of $1.2-\mathrm{M} \mathrm{n}-\mathrm{Bu} 4 \mathrm{NI}$ in methanol solution and $10 \mathrm{ml}$ water; the mixture was shaken and then centrifuged to remove the insoluble $\left(B u_{4} N\right)_{2} F_{4} S_{4}(S P h)_{4}$ in the form of voluminous precipitate. The supermatant liquid was filtered and the $\mathrm{pH}$ adjusted to about 9 with dilute NaOH. The solution was allowed to pass slowly through an anion-exchange colum (i.d. $0.6 \mathrm{~cm}$, filled to a volume of $2.0 \mathrm{ml}$ with a strong-base type \#717 anion-exchange resin in the chlorids form). The column was rinsed with $60 \mathrm{ml}$ of distilled water made slightly alkaline ( $\mathrm{pH} 9$ ) with dilute NaOH. It was then eluted with $1.0 \mathrm{M}$ $\mathrm{KCl}$ acidified with dilute $\mathrm{HCl}$ to $\mathrm{pH} 2$, and the eluted solution allowed to run into a receiver containing a small amount of solid NaOH sufflcient to make the solution slightly alkaline, in which ATP hydrolysis was found to be very slow. The $\mathrm{Pi}$ content was then determined by the modified Baginski's molybdenum blue method (ref. 13). The reference sample containing the same amounts of ATP and the cluster, but without the hydrogen peroxide, was similarly treated, and the amount of Pi determined was used as blank correction. Each experiment was run in duplicates. Three series of experiments were performed with three different ratios of DMF: $\mathrm{H}_{2} \mathrm{O}$ since the extent of ATP hydrolysis was found to vary with the composition of the mixed solvents.

\section{RESULTS AND DISCUSSIONS}

As shown in Fig. 1, treatment of ATP with $\left(\mathrm{Fe}_{4} \mathrm{~S}_{4}(\mathrm{SPh})_{4}\right) 2-$ in DMF-H $\mathrm{O}(4: 1 \mathrm{v} / \mathrm{v})$ caused the $31 \mathrm{P}$ n.m.r. peaks of the $\alpha-, \beta-$, and $\boldsymbol{\gamma}-\mathrm{PO}_{4}$ of ATP to shift downfield by about 8.2 ppm, 7.9 ppm, and $10 \mathrm{ppm}$, respectively, with the $\beta$ - 1 P n.m.r. peak very much broadened and the $\gamma-31 \mathrm{P}$ n.m.r. peak greatly suppressed. This appeared to be quite similar to the downfield shifts of the $\alpha, \beta-$, and $\gamma^{3} \mathrm{P}$ n.m.r. peaks of MgATP by about $8.7 \mathrm{ppm}, 9.0 \mathrm{ppm}$, and $7.7 \mathrm{ppm}$, respectively, caused by the additon of the reduced Fe-protein to MgATP, as observed by Mortenson and Upchurch (ref. 11). Note that additon of $\mathrm{MgCl}_{2}$ to the ATP, or to the ATP$\left(\mathrm{Fe}_{4} \mathrm{~S}_{4}(\mathrm{SPh})_{4}\right)^{2}-$ system in DMF- $\mathrm{H}_{2} \mathrm{O}$ made no appreciable difference to the $31 \mathrm{P}$ n.m.r. spectra, and that additon of an equivent amount of $\mathrm{HSC}_{2} \mathrm{H}_{4}$ OH to ATP in DMF- $\mathrm{H}_{2} \mathrm{O}$ did not produce any shifting in the $31 \mathrm{P}$ n.m.r. peaks.

Chen et al. (ref. 8) have shown that addition of ATP to (Fe4 S4 (SPh) 4 )2- suppressed the polarographic half-wave of the cluster at $-100 \mathrm{~V}$ and produced a new half-wave at $-1.49 \mathrm{~V}$ (Fig. 2). This again is qualitatively analogous to the shifting of the redox potential of the reduced Fe-protein by about -0.1 to $-0.2 \mathrm{~V}$ due to the addition of MgATP (or MgADP) (rev. in ref. 1,2). They have also observed that the electronic absorption peak of the cluster $\left(\mathrm{Fe}_{4} \mathrm{~S}_{4}(\mathrm{SPh})_{4}\right)$ 2- at $458 \mathrm{~nm}$ was suppressed by the addition of ATP (Fig. 3), and that ATP (ADP, $\mathrm{P} i$, AMP) promoted the redox reaction between the cubane-like cluster and methylene blue, the 
observed order of decreasing extent of rate promotion being $A T P>A D P \sim P_{i} \gg A M P$.

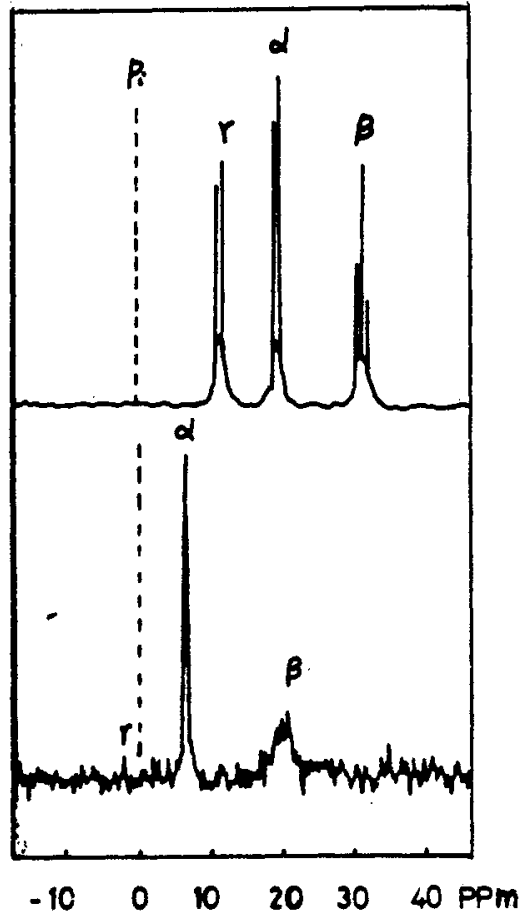

Fig. 1. Shifting of 31P n.m.r. peaks of ATP due to addition of $\left(\mathrm{Fe}_{4} \mathrm{~S}_{4}(\mathrm{SPh})_{4}\right) 2-$

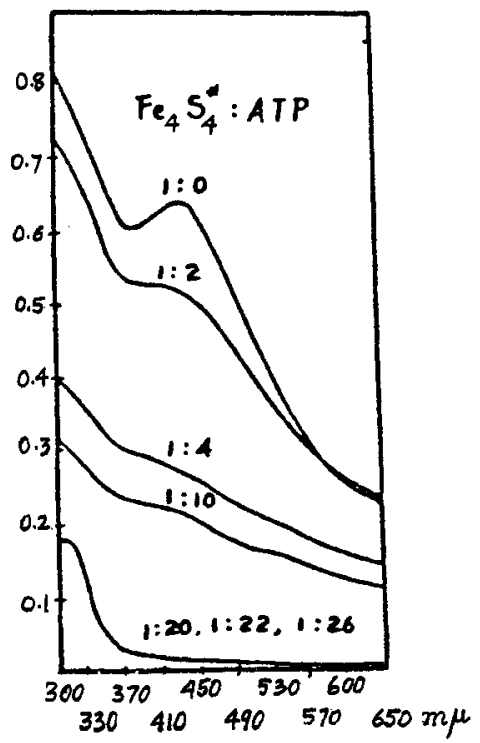

Fig. 3. Effect of ATP on electronic absorption of $\left.\mathrm{Fe}_{4} \mathrm{~S}_{4}(\mathrm{SPh})_{4}\right)^{2-}$

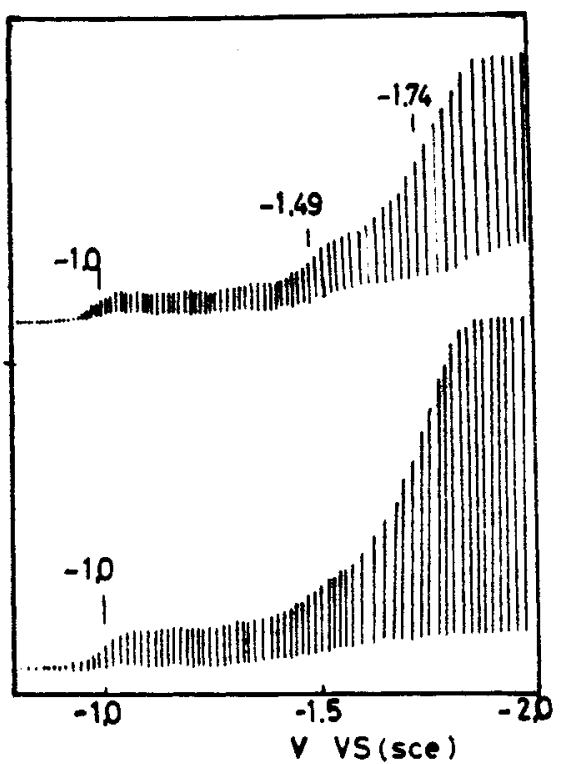

Fig. 2. Shifting of polarographic half-wave of (Fe4S4(SPh)4)2- due to addition of ATP, or MgATP

These experimental results of chemical modeling strongly indicate that ATP can complex with (Fe4S4(SPh)4)2-, and that MgATP is most probably coordinated directly to the $4 \mathrm{Fe}-4 \mathrm{~S}$ center of the Feprotein.

No thiophenol was detected after the cubane-like cluster $\left(\mathrm{Fe}_{4} \mathrm{~S}_{4}(\mathrm{SPh})_{4}\right)\left(\mathrm{NEt}_{4}\right)_{2}$ in $\mathrm{DMF}-\mathrm{H}_{2} \mathrm{O}$ was treated with ATP, showing that complexation with ATP did not displace any of the thiolate ligands on the cluster. Thus ligation of ATP to any of the Fe(II,III) probably took place simply by changing the tetrahydral coordination of the metal ion into trigonal-bipyrimidal coordination, resulting in an increase in ligand field acting on the cluster anion to exert additional driving force for the electron outflow.

It is astonishing to find that complexation of ATP with the cubane-like cluster did not appear to shield the cluster from disruption by the iron chelater, phenanthroline in DMF-H2O $(3: 2 \mathrm{v} / \mathrm{v}, \mathrm{pH}$ 7.5); instead, it enhanced the rate of development of the characteristic absorption peak of Fe(II)-phen complex at $510 \mathrm{~nm}$ (Fig. 4), as did ADP to a smaller extent. Again this is qualitatively analogous to the dramatic sensitization, by the addition of MgATP, of the $4 \mathrm{Fe}-4 \mathrm{~S}$ center of $\mathrm{Fe}$-protein to disruption by iron chelaters (ref.1,2).

A plausible explanation is as follows: In either case the complexation of 2ATP, or 2MgATP in the case of the Fe-protein, with the $4 \mathrm{Fe}-4 \mathrm{~S}$ cubane-like cluster is fast and reversible, as indicated by the n.m.r. 31p peaks broadening; theds at certain instances only one face of the cubane-like 4Fe-4S cluster is ligated with ATP, or MgATP in the case of the Fe-protein, and the valence dislocalization of Fe(II,III) in the cluster is broken up, with the ATP, or MgATP, preferentially coordinated to the $\mathrm{Fe}$ (III), leaving the $2 \mathrm{Fe}$ (II) on the opposite face of the $4 \mathrm{Fe}-4 \mathrm{~S}$ cubane-like cluster coordinatively unsaturated and open to attack by the Fe(II) 
chelater phenanthroline. In the case of the Fe-protein, complexation of MgAtP to the $4 \mathrm{Fe}-4 \mathrm{~S}$ center on one face might also produce some conformational change with the two protein subunits open up a little so that the opposite face the $4 \mathrm{Fe}-4 \mathrm{~S}$ center is rendered more accessible to phen, or reductant. It is to be noted that, with higher proportion of DMF in DMF- $\mathrm{H}_{2} \mathrm{O}$ (e.g., $4: 1 \mathrm{v} / \mathrm{v})$, some inhibition of the cubane-like cluster $\left(\mathrm{Fe}_{4} \mathrm{~S}_{4}(\mathrm{SPh})_{4}\right) 2$ - by ATP or ADP, from attack by phen was observed; probably here the Fe(II) of the opposite face of the cluster is partially protected by solvation withloMF.

As shown in Fig. 5, the rate of redox reaction between the $\left(\mathrm{Fe}_{4} \mathrm{~S}_{4}(\mathrm{SPh})_{4}\right) 2$ - and indigo carmine was found to be significantly enhanced by the addition of ATP, and to a smaller extent by the addition of ADP or Pi, while AMP is almost ineffective. This is in the order of increasing steric hindrance if ATP, ADP, and AMP are all coordinated to the Fe(II, III) of the $4 \mathrm{Fe}-4 \mathrm{~S}$ center through their terminal $\mathrm{PO}_{4}$. Similar order of decreasing rate enhancement in the redox reaction between the cluster and methylene blue has been reported by Chen et al. (ref. 8).

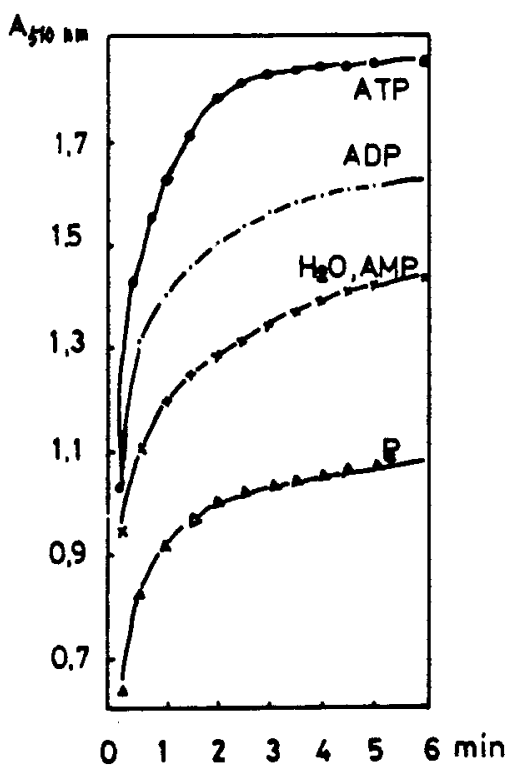

Fig. 4. Sensitization of cluster disruption by phen due to addition of ATP or ADP in DMF- $\mathrm{H}_{2} \mathrm{O}$ $(3: 2 \mathrm{v} / \mathrm{v}, \mathrm{pH} 7.5)$

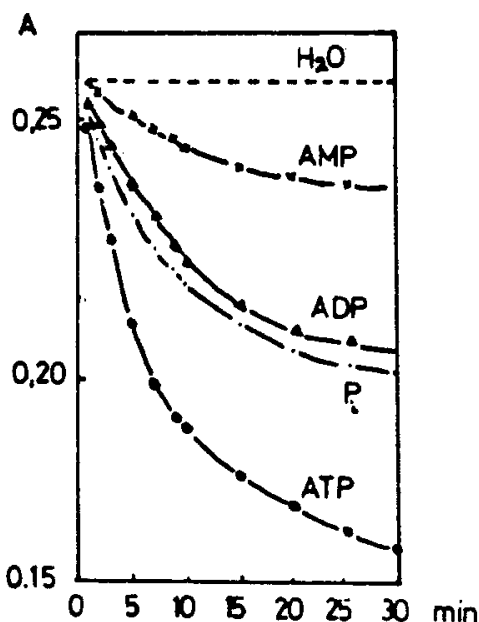

Fig. 5. Promotion of redox reaction between $\left(\mathrm{Fe}_{4} \mathrm{~S}_{4}(\mathrm{SPh})_{4}\right)^{2-}$ and indigo carmine by ATP (ADP, $\mathrm{P}_{i}, \mathrm{AMP}$ ) in DMF- $\mathrm{H}_{2} \mathrm{O}$

However, no ATP hydrolysis was detected in the sample after the redox reaction and removal of the dye and the cluster by extraction with chloroform.

Small extents of ATP hydrolysis were observed, however, by oxidation of the cubane-like cluster $\left(\mathrm{Fe}_{4} \mathrm{~S}_{4}(\mathrm{SPh})_{4} \mathrm{R}\right.$ - with hydrogen peroxide in the presence of ATP in DMF-H $\mathrm{O}$, and the extent of ATP hydrolysis was found to decrease with increasing proportion of DMF in the mixed solvents. Thus with DMF- $\mathrm{H}_{2} \mathrm{O}(3: 2 \mathrm{v} / \mathrm{v})$ containing 30 umol of the cluster, 30 umol ATP and 60 umol $\mathrm{H}_{2} \mathrm{O}_{2}$ in $30 \mathrm{ml}$ of solution, the extent of ATP hydrolysis after correction for blank ( $1.26 \mu \mathrm{mol}$ $\mathrm{Pi}$ liberated) was $2.44 \mathrm{umol}$, i.e., ca $8.1 \%$ of the total ATP; and with $\mathrm{DMF}-\mathrm{H}_{2} \mathrm{O}(3: 2 \mathrm{v} / \mathrm{v}) \mathrm{con}-$ taining 15 umol of the cluster, and $60 \mu \mathrm{mol}$ of ATP, and 30 umol of $\mathrm{H}_{2} \mathrm{O}_{2}$, the extent of hydrolysis was found to be $14.4 \%$ of the cluster as the limiting factor; while with $3.0 \mathrm{ml}$ of DMF$\mathrm{H}_{2} \mathrm{O}(4: 1 \mathrm{v} / \mathrm{v})$ containing $30 \mathrm{umol}$ of the cluster, 30 umol ATP, and 60 umol $\mathrm{H}_{2} \mathrm{O}_{2}$, the extent of ATP hydrolysis at $30^{\circ} \mathrm{C}$ was only about $4.2 \%$ of the toal ATP after correction for blank, ion-exchange method being used in each determination for the isolation of the liberated $\mathrm{Pi}$.

According to Haight et al. (ref. 14), hydrolysis of ATP or triphosphate coordinated in certain mode of chelation on VO2+ or Mn $2+$ was greatly enhanced by oxidizing the VO2+ or $\mathrm{Mn} 2+$ with hydrogen peroxide; and rate enhancement of the order of 104 to 106 times for the hydrolysis of ATP or triphosphate could be obtained simply by complexation with vo3+or $\mathrm{Mn}^{3+}$. Haight et al. (ref. 15) have also found that triphosphate coordinated as tridentate ligand on Co(III) was hydrolyzed by attack from adjacent nucleophile at pH 7.3 about $10^{6}$ times faster than the uncoordinated triphosphate. However, no work has been reported in the literature on the hyorolysis of ATP or triphosphate coordinated on iron-sulfur clusters. With the cubanelike $\left(\mathrm{Fe}_{4} \mathrm{~S}_{4}(\mathrm{SPh})_{4}\right) 2-, 3-$ clusters each with $6 \mathrm{M}-\mathrm{M}$ bonds and formal number of electrons in the 
coordination sphere equal to 66 , or 67 , respectively, each of the Fe(II,III) can easily accommodate an additional monodentate (but not bidentate!) ligand to assume a trigonal-bipyrimidal coordination with only a slight readjustment of the position of the thiolate ligand. Thus ATP (or MgATP), or ADP (or MgADP) can easily coordinate to it as a monodentate ligand through the $\gamma$ or $\mathrm{B}-\mathrm{PO}_{4}$; but the of $\mathrm{PO}_{4}$ appears to be ineffective due to the proximity of the bulky adenyl group. The internuclear distance of each pair of adjacent Fe(II, III) of the cubane-like cluster (ref. 9,10 ) is about 2.70 to $2.76 \AA_{i}$ so, ATP or MgATP molecule may also be coordinated as a bridge-ligand with the $0-$ and B-phosphonyl oxygen atoms spanning two Fe (II, III) at about $2.85 \&$ internuclear distance with relaxation of the $M$-M bond. Thus the formal total numbers of electrons in the coordination spheres of the 4Fe(II, III) will be increased to 70 and 71 , respectively, comparable with $\left[\mathrm{Fe}_{4} \mathrm{~S}_{4}\left(\mathrm{~S}_{2} \mathrm{C}_{2}\left(\mathrm{CF}_{3}\right)_{2}\right)_{4}\right]$ 2- with $4 \mathrm{M}-\mathrm{M}$ bonds (ref. 16) and formally 70 electrons, and with $\left[\mathrm{Fe}_{4} \mathrm{~S}_{4}(\mathrm{SPh})_{2} \text { (dtc) }{ }_{2}\right]^{2-}$ with $5 \mathrm{M}-\mathrm{M}$ bonds (ref. 17) and formally 68 electrons (for each $M-M$ bond, the electron pair being counted twice). Thus these iron-sulfur clusters are still coordinationally unsaturated in the sence that the formal total number of electrons in the coordination sphere of the $4 \mathrm{Fe}$ (II, III) is still less than 72. In DMF- ${ }_{2} \mathrm{O}, \mathrm{ATP}$ appears to coordinate predominantly as a monodentate ligand, and only a small part as bridge ligand, probably due to strong conpetition from DMF for the coordination site. Conceivably, this part of ATP coordinated as bridge-ligand is much more susceptible to hydrolysis by nucleophilic attack, especially when the $4 \mathrm{Fe}-4 \mathrm{~S}$ core becomes more positively charged due to the loss of an electron in the redox reaction. This may be the reason why only a small extent of ATP hydrolysis was observed with the model system in DMF- $\mathrm{H}_{2} \mathrm{O}$. In the case of Fe-protein-2MgATP complex, there is no competition from strongly ligating solvent molecules; furthermore, the $2 t$ may be constrained by the micro-environment inside the Fe-protein to coordinate only as bridge-ligands through the $\gamma$ - and $\mathrm{B}-\mathrm{PO}_{4}$, so that hydrolysis of the anhydride linkage by nucleophilic attack from adjacent nucleophile inside the protein micro-environment is greatly promoted attending the electron outflow from the $4 \mathrm{Fe}-4 \mathrm{~S}$ center. This large rate enhancement makes the ATP hydrolysis and the protein-protein electron-transfer appear as practically concurrent events, both being limited by the rate of protein-protein complexation in the $40-45 \mathrm{~ms}$ range. A probable mode of bridge-type coordination of the $2 \mathrm{t}$ in [ $\left.2 \mathrm{t}^{\mathrm{t}}\right]$ is shown in Fig. 6. Note that a strong support of this bridge-type coordination is as follows: considering only the two $\mathrm{O}_{3} \mathrm{POPO}_{3}$ and the $4 \mathrm{Fe}-4 \mathrm{~S}$ core with 4 thiolate ligands, we see a near $\mathrm{S}_{4}$ local symmetry of the cluster-2MgATP complex, in accord with the near axial symmetry indicated by the e.p.r. signal of $[2 \mathrm{st}]$, as observed Mortenson and Walker (rev. in ref. 1). A probable mode of coordination of MgADP as monodentate ligand is shown in Fig. 7.

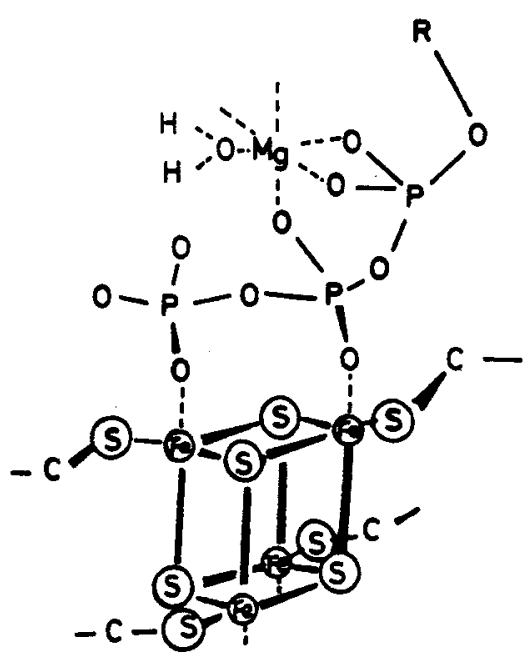

Fig. 6. Probable mode of coordination of $2 t$ in $[2 t s]$ with local $\frac{T}{4}$ axial symetry

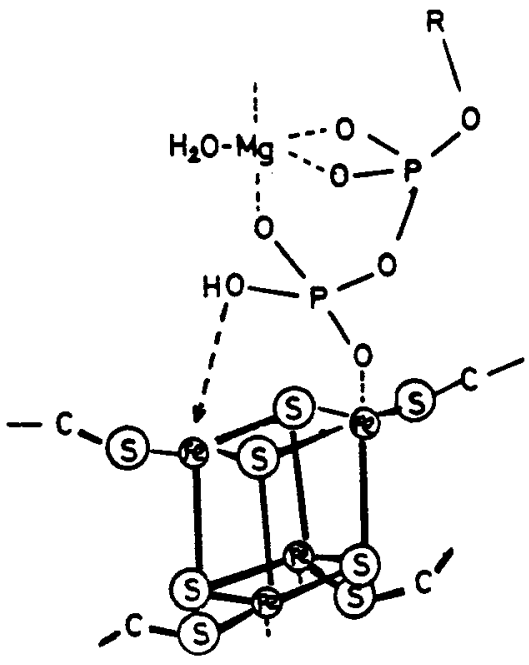

Fig. 7. Probable mode of coordination of $2 \underline{\alpha}$ in $[2 \mathrm{dd}]$

Fig. 8 is a diagram showing the nitrogenase-catalyzed reaction pathways for a mechanism of 2-step ATP-driven electron-transfer, which takes into account the following points: (a0 ATP hydrolysis takes place only in the electron outflow from the reduced Fe-protein to MoFe-pro\% tein (ref. 18); (b) with more concentrated solution of nitrogenase from $\mathrm{K}$. pneumoniae (Kp), the dissociation of the enzyme complex [1, ] $\left.2{ }_{0}^{\mathrm{dd}}, 2 \mathrm{Pi}\right]$ after the protein-protein electrontransfer may be the rate controlling step of the enzyme turnover (ref. 19); and (c) there is the possibility that [ ${ }_{\mathrm{td}}^{\mathrm{td}}$ ] might also have sufficiently negative redox potential to drive the protein-protein electron-transfer in order to account for the observation by Mortenson Upchurch (ref. 11) that, with appropriate ratio of $\mathrm{d} / \mathrm{t}$ (in the range of 0.3 to 0.5 ) and with dilute $C p$ nitrogenase, the ATP/2e ratio could be as Jow as 2 . 
For an enzyme system $\left\{1_{s}\right):\left(2_{s}\right)$ with sufficient supplies of reductant and ATP, the initial step is the complexation of (2s] with $2 t$ followed by complexation with [ls] to form the enzyme camplex $\left[1_{s}\right][2 t t]$. After that the main reaction pathway proceeds in cycle along the steps $(2)-(3)-\left(4^{\prime}\right)-\left(4^{\prime}\right)-(5)-(6)-(7)-(2)$, and a secondary reaction pathway along the steps $(2)-(3)-\left(4^{\prime}\right)-\left(4^{\prime} '\right)-(12)-(13)-(14)-(15)-(1)-(2)$, with the step (3)! as the rate-determining step for either pathway; so most of the enzyme system under this steady state conditions of the enzyme turnover will be in the e.p.r. silent state [10][2dd], as observed by Smith et al. (ref. 19). Two other secondary reaction pathways will be of minor importance, or practically negligible, if the relative concentrations of $t, d$, ( $t / d$ ratio large), and of reductant (small compared with $t$ ) are such that step (5') añd step (12') are both very slow compared with step (4''). If this is the case and only these four reaction pathways are considered, then the ATP/2e ratio will be practically equal to 4 , or slightly less than 4 . However, there is alway some chance for the reductant independent ATP-dydrolysis reaction-cycle (3)$(8)-(9)-(10)-(11)-\left(1^{\prime}\right)-\left(2^{\prime}\right)-(3)$ to occour, especially when [10] is about qual to, or large than [20] in molar concentration, or when the two protein components complex with each other unusally firmly (as in the case of certain cross components, like Kpl:Av2),; so, the overall ATP/2e ratio is usually greater than 4 . For an enzyme system [ $\left.1_{\mathrm{s}}\right]:[2 \mathrm{~s}$ ] with sufficient supply of reductant but limited supply of ATP, step (8) will become more and more important campared with step ( $\left.4^{\prime}\right)$ when $t$ is being used up; and when $t$ is exhausted, steps (4') and (II) can no longer proceed, so the enzyme system will end up with the state [ $\left.1_{s}\right][2 \mathrm{~d}]$, or its dissociated state $\left[l_{s}\right]:\left[2 \frac{d}{g}\right]$, or $\left[1_{s}\right]:\left[2 d_{s}\right]$ with both components e.p.r. active. On the other hand, if $t$ is sufficient, but reductant exhausted, then steps (5), (5'), and (15') can not proceed, so the enzyme system will end up with the state $\left[1_{s}\right][2 \mathrm{tt}]$, or $\left[1_{s}\right]\left[2_{0}^{t d}\right],\left[1_{s}\right]:[2 t d]$ states, showing only the e.p.r. signals of the semi-reduced MoFe-protein; in accord with the observations of Mortenson and Walker (ref. 7) and Smith et al. (ref. 19). From Fig. 8 it can be inferred that, the appropriate conditions for observing an ATP/2e ratio small than 4 (this, however, has not been reported elsewhere) would seem to be the use of very dilute enzyme solution with a fairly large excess of the Fe-protein, very high concentration of reductant, and high concentrations of $t$ and $d$ with appropriate ratio of $t / d(0.3$ to 0.5$)$, so that the enzyme reaction proceeds predaminantly by the pathway $\left(2^{\prime}\right)-\left(3^{\prime}\right)-\left(4^{\prime}\right)-\left(5^{\prime}\right)-\left(6^{\prime}\right) !-\left(7^{\prime}\right)-$ $\left(2^{\prime}\right)$, and the secondary pathway $(3)-(4)-\left(12^{\prime} !-\left(13^{\prime}\right)-\left(14^{\prime}\right)-\left(15^{\prime}\right)-\left(1^{\prime}\right)-\left(2^{\prime}\right)-(3)\right.$, with compara-

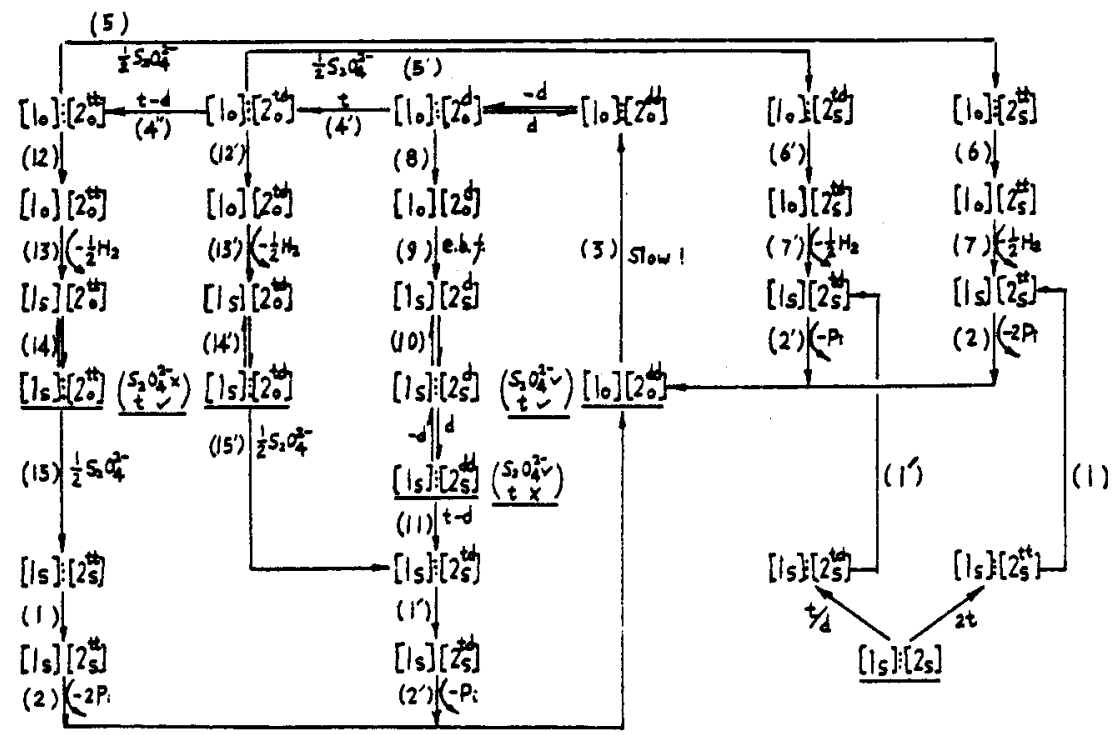

Fig. 8. Diagram showing reaction pathways for a mechanism of 2-step ATPdriven electron transfer. $S_{2} Q_{4} V$ or $x$, and/or $t$ Vor $x$ denote sufficient or insufficient supply of reductant and/or $t$. For other notationsee text.

tively small probability for electron backflow because step (8) will be very slow compared with (4') under the above conditions with $\mathrm{S}_{2} \mathrm{O}_{4}>t \mathrm{t}$ a d d $\gg[2] \gg[1]$. Finally the reductantindependent, nitrogenase-catalyzed ATP-hydrolysis reaction pathway is easily seen from Fig. 8 to be the cyclic sequence of setp: $(3)-(8)-(9)-(10)-(11)-\left(1^{\prime}\right)-\left(2^{\prime}\right)-(3)$, with ATP/2e $\rightarrow \infty$. This will take place to a greater extent if $\left[I_{0}\right]>\left[2_{0}\right]$, or if $\left[I_{0}\right]$ has a strong affinity to bind $[20]$, as in the case of the tight-binding cross components Avl and Cp2 (ref. 20).

\section{CONCLUDING REMARKS}

Chemical modeling experiments show that ATP, or MgATP, can complex with the cubane-like 
cluster $\left(\mathrm{Fe}_{4} \mathrm{~S}_{4}(\mathrm{SPh})_{4}\right) 2-$ (without displacing any of the thiolate ligands), resulting in downfield shifting of the 31p n.m.r. peaks of ATP by about 8-10 ppm, in sensitizing the cluster to disruption by phenanthroline in DMF- $\mathrm{H}_{2} \mathrm{O}(3: 2 \mathrm{v} / \mathrm{v})$, and in shifting the redox potential of the cluster to more negative value to promote electron outflow. All these are analogous to the effects of complexation of MgATP with the Fe-protein, indicating direct coordination of MgATP to the 4Fe-4S center of the Fe-protein to drive the electron-transfer. Oxidation of the $\left(\mathrm{Fe}_{4} \mathrm{~S}_{4}(\mathrm{SPh})_{4}\right)^{2-}$ with hydrogen peroxide in $\mathrm{DMF}-\mathrm{H}_{2} \mathrm{O}(3: 2 \mathrm{v} / \mathrm{v})$ promotes ATP hydrolysis to a small extent of about 8-14\%. In this medium, ATP appears to coordinate to the cluster predominantly as a monodentate ligand through the terminal $\mathrm{PO}_{4}$; whereas in the Fe-protein, the 2 MgATP are most probably constrained by the miro-environment inside the protein to coordinate to the $4 \mathrm{Fe}-4 \mathrm{~S}$ center only as bridge-ligands through the $\gamma$ - and $\mathrm{B}-\mathrm{PO}_{4}$, thus they are conceivably much more susceptible to hydrolysis by nucleophilic attack from adjacent nucleophile in the electron outflow fram the reduced Fe-protein.

\section{REFERENCES}

1. W.G. Zumft and L.E. Mrtenson, Biochem. Biophys. Acta 416, 1-52 (1975).

2. W.H. Orme-Johnson, Ain. Rev. Biophys. Chem. 14, 419-59 (1985).

3. R.N.F. Thorneley and D.J. Lowe, Biochem. J. 215, 393-403 (1983).

4. K.R. Tsai and H.L. Wan, in Fund. Res. Organomet. Chem., p.1-12. M. Tsutsui, Y. Ishi, and Huang Yaozheng, eds. University Park Press, Baltimore (1982).

5. (a) Nitrogen Fixation Research Group of Xiamen Univer sity, J. Xiamen University (Nat. Sci.) 13, (1) 111-126 (1974); Scientia Sinca (Engl. Ed) 19, 460-478 (1976)

(b) K. R. Tsai, in Nitrogen Fixation I - p.373. W.E. Newton and W.H. Onme-Johnson, eds. Univer_sity Park Press, Baltimore (1980).

6. G.D. Lin et al., Absţr. INOR-0016, 186th ACS Nat. Mtg. (1983).

7. M. Walker and L.E.Mortenson, B.B.R.C. 54, 669-676 (1973).

8. H.B. Chen et al., J. Xiamen University (Nat. Sci.) 24., 448-456 (1985).

9. R.H. Holm et al., J. Am. Chem. Soc. 95, 3523-3534 (1973).

10. G. Christou and D.C. Garner, J. Chem. Soc. Dalton 1093-1094 (1979).

11. L.E. Mortenson and Upchurch, R.C. in Current Perspectives in Nitrogen Fixation, p.75-77. A.H. Gibson and W.E. Newton, eds. Australian Academy of Science Press, Canberra (1981).

12. K.R. Kunkel, Anal. Chem. 31, 1091-1094 (1959).

13. E.S. Baginski, P.P. Foa, and B. Zak, Clin. Chim. Acta 15 (1), 155-158 (1967).

14. (a) G.M. Waltermann et al., Inorg. Chem. 16, 2985-2987(1977);

(b) G.P. Haight et al., in Molybdenum Chemistry of Biological Significance, p. 389-400. W.E. Newton and S. Otsuka. eds. Plenum Press (1980).

15. G.P. Haight, Jr. et al., J. Chem. Soc. Commun. Chem. 488-491 (1985).

16. I. Bernal et al., J. Coord. Chem. 2, (1), 61-65 (1972).

17. M.G. Kantzidis et al., Inorg., Chem. 22, 179-181 (1983).

18. R.V. Hageman, W.H. Orme-Johnson, and R.M. Burris, Biochemistry 19, 2333-2342 (1980).

19. B.E. Smith, D.J. Lowe, and R.C. Bray, Biochem. J. 135, 331-342 (1973).

20. D. Emerich and R.H. Burris, Proc. Nat. Acad. Sci. (USA) 73,4369 (1976). 